\title{
Model Pendidikan Entrepreneurship Di Pondok Pesantren
}

\author{
Fatchurrohman, Ruwandi \\ IAIN Salatiga, Indonesia \\ artur.neno@yahoo.co.id
}

\begin{abstract}
This study aimed at investigating entrepreneurship education concept; the conduct of entrepeneurship education; and the effect of enterprneurship education in pesantren; and investigating the problems experienced and their solutions. This was a case-study qualitative research. The collected data was analized qualitatively by using Miles and Huberman's interactive model. The findings of the study showed that: entrepreneurship education in pesantren aimed at preparing students (santri) to encounter real life after their graduation. Job affairs have actually been managed by Allah The Al-Mighty, yet humans should prepared themselves by sufficient skills, entrepreneurship activities in pesantren was conducted through the advanced-special program, curriculair, extra-curriculair, and non-curriculair programs, entrepeneurship activities in pesantren contributed a lot to the economic effects and the students' life skill, the coming problems in entrepeneurship activities of pesantren were caused by buman resources, technology and management. To solve such problems, pesantren effortlessly tried to consolidate to the relating partners and improved their entrepeneurship management.
\end{abstract}

Keywords: pesantren (Islamic Boarding Schools), entrepeneurship, education model

\begin{abstract}
Abstrak
Penelitian inibertujuan untukmengetauikonseppendidikan entrepreneurship dipesantren; pelaksanaan pendidikan entrepreneurship; dampak pendidikan entrepreneurship di pesantren; problematika yang dihadapi dan solusi untuk mengatasinya. Penelitian ini termasuk jenis kualitatif dengan pendekatan studi kasus (case study). Analisis data penelitian menggunakan model interaktif Miles \& Huberman. Hasil penelitian menunjukkan bahwa pendidikan entrepreneurship diarabkan untuk mempersiapkan santri dalam menghadapi kehidupan setelah lulus. Urusan pekerjaan sebenarnya sudah diatur Allah, namun manusia harus mempersiapkan diri dengan keterampilan secukupnya. Kegiatan entrepreneurship di pesantren dilaksanakan melalui jalur program khusus unggulan, kurikuler, ekstrakurikuler, dan jalur non-kurikuler. Kegiatan kewirausahaan di pesantren mampu memberi dampak ekonomi dan life skill kepada para santri. Masalab yang muncul dalam kegiatan kewirausahaan di pesantren berasal dari human resources, teknologik, manajemen. Untuk mengatasi masalah tersebut, pihak pesantren selalu melakukan koordinasi dengan pihak terkait dan berusaha memperbaiki manajemen kewirausahaannya.
\end{abstract}

Kata kunci: pesantren, entrepreneurship, model pendidikan

Permalink/DOI: http://dx.doi.org/10.18326/infsl3v12i2.395-416 


\section{Pendahuluan}

Penyelenggaraan pendidikan di pondok pesantren sebagian besar masih mengutamakan materi keagamaan dan akhlak, tetapi sedikit materi keahlian baik hard skill maupun soft skill. Hal tersebut berakibat, banyak lulusan pondok pesantren seringkali menjadi gagap saat kembali ke masyarakat. Susah mencari kerja dan kalau bekerja, sebagian besar dari mereka menjadi pekerja bukan professional, seperti menjadi pedagang biasa di pasar tradisional. Banyak juga alumni pesantren yang menganggur, padahal biaya dan waktu yang mereka butuhkan untuk mencari ilmu di pesantren terkadang lama sekali, hingga belasan tahun atau hampir sama dengan anak-anak yang menempuh pendidikan formal hingga lulus perguruan tinggi. Padahal, seperti anak-anak yang lain, para santripun akan menghadapi tantangan yang tidak kalah kompleksnya di era kompetisi global ini (Handayani, 2013:2).

Menghadapifenomenasepertiitu, pendidikan entrepreneurship menjadi salah satu solusi konkrit untuk lebih memberdayakan pondok pesantren. Disamping semangat kemandirian yang menjadi ciri khas pesantren, penting juga untuk mengajarkan berbagai macam keahlian dan semangat kewirausahaan kepada para santri agar nanti setelah lulus mereka mampu melangsungkan hidup dengan bekerja profesional. Oleh karena itu, pesantren tidak saja mengajarkan ilmu-ilmu agama, namun para santri juga dibekali berbagai hard skill dan soft skill, semangat entrepreneurship, dan penguasaan teknologi informasi yang dibutuhkan untuk kehidupan masyarakat modern.

Pondok Pesantren Bina Insani Susukan dan Pondok Pesantren Al Ittihad Poncol Kabupaen Semarang Kabupaten Semarang merupakan Pondok pesantren yang sampai sekarang masih banyak diminati masyarakat. Menurut Azyumardi Azra (Malik M., dkk, 2007:ix), dinamika inovasi pembaharuan di pondok pesantren, pada sebagian atau keseluruhan aspek telah menjadikan pesantren dan lembaga serupa mampu survive hingga saat ini. Dalam hal ini, pendidikan entrepreneurship di pesantren merupakan salah satu inovasi untuk survival pesantren itu sendiri di tengah gelombang arus tantangan modernitas. Penelitian ini memaparkan upaya pesantren tersebut dalam pendidikan entrepreneurship kepada para santri. 
Ada beberapa fokus masalah yang dikaji melalui penelitian ini, yaitu; 1) Bagaimana konsep entrepreneurship (kewirausahaan) yang dikembangkan di pesantren Bina Insani Susukan dan Ponpes Al Ittihad Poncol Kabupaten Semarang; 2) Bagaimana pelaksanaan pendidikan entrepreneurship di pesantren Bina Insani Susukan dan Al Ittihad Poncol Kabupaten Semarang? 3) Bagaimana dampak pendidikan entrepreneurship di pesantren terhadap performa para santri, lulusan dan masyarakat ?; 4) Apa problematika yang dihadapi pesantren dalam pendidikan entrepreneurship? Bagaimana solusi untuk mengatasinya?

\section{Kajian Teori}

\section{Pengertian dan tujuan pesantren}

Pondok pesantren merupakan sebuah lembaga pendidikan tradisional, dimana para siswanya (santri) tinggal bersama dan belajar di bawah bimbingan guru yang lebih dikenal dengan sebutan Kyai dan mempunyai asrama untuk menginap para santri. (Zamakhsyari Dhofier, 1983:18).

Diantara tujuan dan fungsi pesantren adalah sebagai lembaga penyebaran agama Islam, agar di tempat tersebut dan sekitar dapat dipengaruhi sedemikian rupa, sehingga yang masyarakat yang sebelumnya tidak atau belum pernah menerima ajaran agama Islam dapat berubah dan menerimanya bahkan menjadi penganut agama Islam yang taat. Sedangkan pesantren adalah tempat mempelajari agama Islam, dimana aktivitas utama adalah adalah mempelajari dan mendalami ilmu pengetahuan agama Islam (Rusli, 2010:4). Di pondok pesantren terdapat elemen dasar, yang meliputi pondok, masjid, pengajaran kitab klasik, santri, dan kyai.

\section{Tipologi}

Seiring dengan perkembangan zaman dan tuntutan masyarakat atas kebutuhan pendidikan yang sempurna, kini banyak pesantren yang menyediakan pendidikan umum di pesantren, sehingga muncul istilah pesantren salaf dan pesantren khalaf. Pesantren 
salaf adalah pesantren yang murni mengajarkan materi keagamaan, sedangkan pesantren khalaf telah menggunakan sistem pengajaran modern dan kurikulum pendidikan formal dari pemerintah (Rusli, 2010:7).

\section{Prinsip-prinsip pendidikan}

Menurut Nurcholis Madjid (dalam Nata 2001:113), prinsip yang melekat pada pendidikan pesantren adalah teosentrik, keikhlasan dalam pengabdian, sederhana, kolektivitas (barakatul jama'ah), mengatur kegiatan bersama, kebebasan terpimpin, mandiri, tempat menuntut ilmu dan mengabdi, mengamalkan ajaran agama, belajar di pesantren bukan untuk mencari ijazah, dan kepatuhan mutlak kepada kyai.

\section{Pola Hubungan Kyai dan santri}

Pola relasi kyai - santri di pesantren dapat dibedakan menjadi tiga bagian, yaitu hubungan guru dan murid, hubungan orang tua anak, dan hubungan patron client.

Dalam hubungan guru dan santri, menurut Nurcholis Madjid (1997:23) santri akan senantiasa memandang Kyai atau gurunya sebagai orang yang mutlak harus dihormati, bahkan dianggap mempunyai kekuatan ghaib yang membawa keberuntungan (berkah) atau celaka (mudarat). Oleh karenanya, santri selalu berusaha untuk patuh kepada Kyai agar mendapat ilmu yang bermanfaat dan menghindarkan diri dari sikap yang mengundang kutukan dari Kyai.

Dhofier (1980:82) berpendapat bahwa, dalam tradisi pesantren, rasa hormat dan ketaatan santri pada kyai bersifat mutlak dan tidak boleh putus, berlaku selama seumur hidup santri. Menurut Nurcholis Madjid (1997:24), hubungan ketaatan santri pada kyai tersebut salah satunya dipengaruhi oleh kajian wajib di pesantren terhadap kitab ta'lim muta'alim karya Al Zarnuji. Ahmad Tafsir menambahkan bahwa kewibawaan seorang kyai juga bersumber dari kemampuan suprarasional Kyai, , walaupun sebenarnya sulit 
dibuktikan kebenarannya namun kepercayaan masyarakat akan hal tersebut sangatlah besar. Peranan kyai sebagai orangtua, kyai merupakan tempat bagi santri untuk mengadu, terutama jika santri memiliki masalah yang tidak dapat diselesaikan sendiri (Galba, 2004:64).

Hubungan patron-client adalah hubungan kyai dan santri yang diwarnai kepercayaan, kewibawaan, dan kharisma. Nilai-nilai yang ada di pesantren, menurut Sukamto (1999:79), mengandung tiga unsur yang mengarah pada terbentuknya hubungan patron-client, yaitu: 1) hubungan patron-client didasarkan pada pertukaran yang tidak seimbang; 2) hubungan patron-client yang bersifat personal. Pola resiprositas yang personal antara kyai dan santri menciptakan rasa kepercayaan dan ketergantungan, bahkan penghormatan santri kepada kyai cenderung bersifat kultus individu; 3) hubungan patron tersebar menyeluruh, fleksibel dan tanpa ada batas kurun waktunya.

\section{Pengertian dan nilai Entrepreneurship}

Entrpreneurship, menurut Kauffman didefinisikan sebagai transformasi inovasi menuju perusahaan yang berkelanjutan yang menghasilkan nilai (value). Kewirausahaan menggabungkan visi dan kerja nyata. Babson mendefinisikan entrepreneurship sebagai cara berpikir dan bertindak yang mampu memanfaat seluruh peluang yang ada melalui pendekatan dan kepemimpinan yang berimbang; sedangkan pendidikan entrepreneurship diartikan sebagai suatu penjelasan yang memahamkan tentang keterampilan, pengetahuan dan proses inovasi dan penciptaan usaha baru (Jeane, 2010:22). Dengan demikian, dapat dipahami bahwa entrepreneurship adalah cara berpikir dan bertindak kreatif dan inovatif dengan senantiasa melihat peluang secara menyeluruh yang dikelola dengan pendekatan kepemimpinan visioner yang seimbang.

Menurut Novan (2012:39), ada nilai-nilai keunggulan pribadi yang dimiliki oleh seorang entrepreneur, yaitu percaya diri, orisinalitas, berorientasi pada manusia, berorientasi hasil kerja, berorientasi masa depan, dan berani mengambil resiko. 
Tabel 1. Nilai-nilai entrepreneurship

\begin{tabular}{|c|c|c|}
\hline No & Nilai entrepreneurship & Indikator \\
\hline 1 & Percaya diri & $\begin{array}{l}\text { Keyakinan, kemandirian, } \\
\text { individualitas, optimis }\end{array}$ \\
\hline 2 & Berorientasi tugas dan hasil & $\begin{array}{l}\text { Kebutuhan akan prestasi, } \\
\text { berorientasi pada keuntungan, } \\
\text { tekun dan tabah, kerja keras, } \\
\text { energik, berinisiatif }\end{array}$ \\
\hline 3 & Pengambilan resiko & $\begin{array}{l}\text { Berani mengambil resiko } \\
\text { Menyukai tantangan }\end{array}$ \\
\hline 4 & Kepemimpinan & $\begin{array}{l}\text { Bertingkah laku sebagai } \\
\text { pemimpin, dapat bergaul } \\
\text { dengan orang lain, suka } \\
\text { terhadap saran kritik yang } \\
\text { membangun }\end{array}$ \\
\hline 5 & Keorisinal & $\begin{array}{l}\text { Inovatif } \\
\text { Kreativitas tinggi } \\
\text { Fleksibel } \\
\text { Berjejaring }\end{array}$ \\
\hline 6 & Berorientasi ke depan & $\begin{array}{l}\text { Memiliki cara pandang ke } \\
\text { depan }\end{array}$ \\
\hline 7 & Jujur dan tekun & $\begin{array}{l}\text { Memiliki keyakinan bahwa } \\
\text { hidup itu kerja, } \\
\text { Bekerja itu ibaah }\end{array}$ \\
\hline
\end{tabular}

Model pendidikan entrepreneurship

Menurut Anita (2012:7), pendidikan entrepreneurship di sekolah dapat dilakukan melalui berbagai cara, yaitu terintegrasi dalam seluruh mata pelajaran, terpadu dalam kegiatan ekstrakurikuler, melalui pengembangan diri, perubahan pelaksanaan dari teori ke praktik, pengintegrasian ke dalam bahan ajar, pengintegrasian melalui kultur sekolah, pengintegrasian melalui muatan lokal. 


\section{Proses pendidikan entrepreneurship}

Cope dan Watt menekankan perlunya pembimbingan (mentoring) untuk memahami kejadian penting yang dialami sebagai pembelajaran, sehingga hasil pembelajarannya efektif. Sulivan menekankan pentingnya client-mentor matching untuk keberhasilan pembimbingan. Lebih jauh, Rae menjelaskan bahwa pengembangan kemampuan kewirausahaan dipengaruhi oleh dorongan, nilai dalam individu, kompetensi, pembelajaran, hubungan-hubungan, dan sasaran yang diinginkannya. Sementara itu Minniti dan Bygrave membuktikan melalui model dinamis dalam pembelajaran kewirausahaan, bahwa kegagalan dan keberhasilan wirausaha akan memperkaya dan memperbaharui stock of knowledge, dan sikap wirausaha sehingga ia menjadi lebih mampu dalam berwirausaha (Anita,2012:12).

Materi skill yang diajarkan dalam pendidikan kewirausahaan meliputi fakta versus mitos menentang entrepreneurship, menguji realitas, kreativitas, toleransi ambiguitas serta sikap-sikap, identifikasi peluang, menilai usaha, tindakan mendirikan unit usaha, strategi dalam usaha, menilai karier, menilai lingkungan, penilaian etika, menyelesaikan transaksi, berjejaring, dan memanen (Winardi, 2004:197).

\section{Kendala-kendala entrepreneurship}

Menurut Karl Vesper (Winardi,2004:35), beberapa kendala dalam kewirausahaan meliputi tiadanya konsep bertahan, kurang kenal pasar, kurangnya keterampilan teknikal, kurang modal awal, kurangnya pengetahuan tentang bisnis, puas dengan diri sendiri, tidak ada motivasi, stigma sosial, keterikatan pada pekerjaan, distraksi karena tekanan waktu, problem yuridis, birokrasi yang kaku, proteksionisme dan monopoli, dan kendala karena paten.

\section{Hasil Belajar}

Hasil belajar adalah perubahan perilaku yang terjadi pada individu seusai menjalani proses belajar (Djamarah,1994:23) Siswa 
yang telah belajar akan mengalami perubahan pengetahuan, perilaku, keterampilan dan mental yang lebih baik, sementara dari sisi guru berupa selesainya materi ajar.

Menurut Gagne, ada lima bentuk hasil belajar, yaitu keterampilan intelektual, kemampuan kognitif, informasi verbal, keterampilan motorik dan sikap, nilai. Sementara itu menurut Bloom, hasil belajar pada individu dapat berupa perubahan dalam ranah kognitif, afektif, dan psikomotorik (dalam Dimyati, 2006:206).

\section{Metode penelitian}

Penelitian ini termasuk jenis kualitatif model studi kasus (case study). Lokasi penelitian ini di Pondok Pesantren Salaf Al Ittihad Poncol dan Pondok Pesantren Modern Bina Insani Susukan Kabupaten Semarang. Subjek dalam penelitian ini adalah pimpinan pondok pesantren, pengurus pondok, santri, pengelola unit usaha di pesantren. Teknik pengumpulan data menggunakan observasi, wawancara mendalam, dan dokumentasi. Instrumen pengumpul data yang digunakan berupa pedoman wawancara, pedoman observasi dan pedoman studi dokumen. Teknik analisis data menggunakan model interaktif Miles \& Huberman.

\section{Hasil Penelitian}

\section{Konsep pendidikan entrepreneurship}

Ada perbedaan konsep pendidikan yang melandasi pendidikan entrepreneurship di pesantren modern dan salaf. Pada lembaga pesantren modern, pesantren lebih berpikir proyektif realistif didasarkan pada realitas empirik bahwa banyak lulusan sekolah yang menganggur, sulit mencari pekerjaan dan terkadang menjadi masalah sosial di lingkungan masing-masing.

Pesantren berusaha mendesain pendidikan sedemikian rupa, sehingga lulusannya kelak memiliki keterampilan hidup (life skill) baik hard skill maupun soft skill. Keterampilan hidup ini sangat dibutuhkan untuk eksistensi kehidupan para alumninya kelak, baik kebahagiaan di dunia maupun di akherat. Menurut Muhtar Buchori 
(2001:41), pendidikan harus mengemban dan menjamah the basics anak didik, yaitu pendidikan yang mampu mempersiapkan peserta didik mampu menjalani kehidupan (preparing children for life). Oleh karena itu pendidikan harus dapat menyeimbangkan antara pendidikan jasmani dan rohani, antara pengetahuan alam dengan pengetahuan sosial budaya, dan antara pengetahuan masa kini, masa lampau, dan masa depan.

Pesantren modern telah memiliki cara pandang multiple inteligencies dalam mengembangkan program pendidikannya, sehingga pesantren didedesain dengan enam keunggulan yang berbeda, yaitu pesantren SSB, pesantren Tabfidz, pesantren Kitab kuning, pesantren Seni, pesantren Bahasa, dan pesantren Keterampilan. Keenam jenis keunggulan tersebut diharapkan mampu mewadahi dan mengembangkan ragam kecerdasan yang dimiliki para santri.

Kegiatan pendidikan yang dikembangkan di Pesantren Bina Insani merupakan realisasi dari misi kelembagaan, yaitu mengkaji, menghayati dan mengamalkan ajaran-ajaran Islam yang komprehensif dan rahmatan lil'alamin; menyelenggarakan sistem pendidikan efektif, kompetitif, inovatif dan dinamis, dengan berorientasi pada masyarakat. Pengkajian, penghayatan, dan pengamalan ajaran Islam secara komprehensif diwujudkan melalui kajian dan membekali santri dengan berbagai macam ilmu pengetahuan dan keterampilan yang mampu mengembangkan seluruh dimensi keragam santri, baik itu bidang kinestetik, linguistic verbal, bidang intellectual quotient (IQ), bidang seni-budaya, dan bidang skill motorik. Semua itu dikembangkan dalam rangka memfasilitasi potensi santri dan membekali santri untuk kehidupan masa depannya. Menurut Chatib (2009:xxi), membangun lembaga pendidikan pada hakekatnya adalah membangun keunggulan sumber daya manusia, yang menghargai keragaman potensi (multiple intelligences) manusia mulai dari perencanaan program, pembelajaran dan pencapaian akhir tujuan akhir, yaitu untuk mengoptimalkan potensi sesuai dengan keunggulan yang dimiliki individu yang besangkutan.

Selain itu, pesantren modern berusaha untuk mewujudkan keseimbangan kejayaan, antara kejayaan kehidupan dunia dan 
kejayaan kehidupan di akherat. Hal tersebut dilandasi akan adanya kewajiban setiap muslim untuk mencapai kebahagiaan di dunia dan kebahagiaan di akherat. Ayat al Qur'an yang dijadikan landasan cara pandang tersebut adalah QS. Al Qashash:77

Dan carilab pada apa yang telab dianugerabkan Allab kepadamu (kebahagiaan) negeri akbirat, dan janganlah kamu melupakan bahagianmu dari (kenikmatan) duniawi dan berbuat baiklah (kepada orang lain) sebagaimana Allah telah berbuat baik, kepadamu, dan janganlah kamu berbuat kerusakan di (muka) bumi. Sesunggubnya Allah tidak menyukai orang-orang yang berbuat kerusakan. QS. al Baqarah:201

Berbeda dengan cara pandang di atas, pesantren salaf memiliki konsep pendidikan yang lebih mengedepankan pencapaian kebahagiaan kehidupan akherat dan ridha Allah. Cara pandang ini dipengaruhi oleh visi kembagaan pesantren salaf lebih mengutamakan perwujudan kesalehan akherat dan ridha Allah.

Cara pandang pendidikan yang berkembang di pesantren salaf ini akhirnya dijabarkan dalam kurikulum pendidikan di pesantren. Tujuan pendidikan di pesantren adalah untuk membekali santri dengan ilmu agama dan ilmu hikmah, serta mencari ridha Allah. Pesantren adalah tempat belajar ilmu agama Islam sehingga kegiatan utama di pesantren adalah mempelajari dan mendalami ilmu pengetahuan agama Islam (Rusli, 2010:4).

Upaya yang dilakukan pesantren Poncol Kabupaten Semarang dalam hal urusan pekerjaan santri kelak adalah menganjurkan para santri untuk mengikuti program kejar Paket C (kesataran pendidikan SMA) setelah tamat di madrasah salaf selama kurang lebih 8 tahun. Setelah santri mengikuti pendidikan paket $\mathrm{C}$ maka ia akan memperoleh ijazah yang dapat dia gunakan untuk melanjutkan kuliah atau mencari pekerjaan.

Sebagaimana dikemukakan di depan, bahwa pesantren salaf lebih mengedepankan pencapaian kebahagiaan di akherat kelak, kebahagiaan di dunia bukanlah tujuan utama dalam kehidupan manusia. Para santri senantiasa ditekankan untuk mencapai 
kebahagiaan di akherat, walaupun di dunia tidak mendapat kebahagiaan tidak apa-apa. Landasan Qur'ani yang senantiasa dipegangi kalangan pesantren salaf antara lain QS. al Dzariyat:56

Dan aku tidak menciptakan jin dan manusia melainkan supaya mereka mengabdi kepada-Ku. QS. Al An'am:32; QS. Al Ankabut:64.

Pesantren Al Ittihad tidak memiliki program khusus untuk mempersiapkan para santri mencapai kebahagiaan di dunia melalui pekerjaan yang layak di dunia, karena urusan pekerjaan adalah urusan Allah. Menurut oleh Nurcholis Madjid (dalam Nata 2001:113), bahwa prinsip yang melekat pada pendidikan pesantren meliputi teosentrik, ikhlas mengabdi, sederhana, kolektifitas (barakatul jama'ah), kebersamaan, kebebasan terpimpin, kemandirian, tempat menuntut ilmu dan mengabdi, mengamalkan ajaran agama, tidak mencari ijazah, kepatuhan mutlak kepada kyai.

\section{Pelaksanaan pendidikan entrepreneurship}

Pelaksanaan kegiatan entrepreneurship di pesantren Bina Insani dilakukan secara terencana, terprogram oleh tim yang dibentuk oleh Yayasan. Tim tersebut dibentuk dengan melibatkan berbagai unsur, yaitu unsur tokoh masyarakat, unsur pemerintahan, unsur masyarakat, dan tokoh agama. Pelibatan berbagai unsur terseubut didasari kesadaran bahwa eksistensi lembaga tidak dapat lepas dari peran serta seluruh elemen masyarakat. Tim sembilan tersebut yang memutuskan bahwa pesantren didesain dengan berbagai keunggulan.

Dalam pelaksanaan program pendidikan kewirausahaan, pesantren Bina Insani membangun jaringan dengan berbagai pihak, yaitu Qaryah Thayibah, kelompok tani Al Barokah, Lembaga Riset Muda Indonesia (LRMI), Badan Ketahanan Pangan, Dinas Perikanan dan Kelautan, UIN Jakarta, Kemendiknas, Kemenag. Jaringan dengan berbagai pihak tersebut akan menopang penguatan konsep dan sumber daya dalam pelaksanaan pendidikan kewirausahaan, baik sumber daya yang berupa man, money, dan material. Menurut Tilaar 
(2004:58), salah satu kenyataan pendidikan pada masa orde baru adalah terpisahnya pendidikan dari masyarakat, akibatnya pendidikan terpisah dari kebutuhan masyarakat, dari dunia industri, dan dunia kerja. Dalam kaitan ini, UU Nomor 22 tahun 1999 menyarankan agar mengikutsertakan masyarakat dalam pengelolaan pendidikan.

Menurut Roger Scott, pelibatan guru, orang tua, dan masyarakat dalam manajamen pendidikan dapat meningkatkan rasa kepemilikan mereka terhadap sekolah lebih tinggi, penggunaan resources pendidikan lebih baik, pengawasan kepala sekolah lebih besar terhadap lingkungan sekolah, dan beban sekolah menjadi lebih ringan sehingga diperoleh hasil yang lebih baik pula (dalam Jalal dan Supriyadi, 2001:11,160).

Adapun kegiatan yang dilakukan dengan berbagai mitra pesantren tersebut antara lain dalam pengolahan pupuk cair, pengolahan sampah, resapan air, pengolahan sampah menjadi BBM, kompor sampah, listrik tenaga santri. Dilihat dari jenis usaha tersebut lebih mengarah pada keterampilan kerja modern, bukan keterampilan kerja masyarakat tradisional. Hal ini dipengaruhi oleh tipologi pesantren Bina Insani yang tergolong pesantren modern (khalaf), sehingga berbagai kegiatan yang dikembangkan juga mengarah pada kondisi atau problematika masyarakat modern.

Pesantren Bina Insani juga mengembangkan kewirausahaan dalam bidang pertanian dan pengolahan snack atau makanan tradisional, misalnya dalam bidang pertanian, peternakan lele, kerupuk berbahan baku lele, makanan olahan berbahan baku singkong. Hal ini menunjukkan bahwa pesantren Bina Insani juga mengakomodasi potensi lokal berupa pertanian, peternakan dan bahan baku singkong untuk kemudian diolah dan dikelola dengan sentuhan manajemen modern. Sentuhan manajemen modern pada olahan makanan berbahan lokal dilakukan pada rasa (taste), pengeolahan (producing), kemasan (packing), pemasaran (marketing). Upaya ini dilakukan untuk mengangkat nilai ekonomi potensi-potensi lokal yang selama ini terabaikan dan dianggap tidak bernilai (unvalued).

Dalam pelaksanaannya, kegiatan kewirausahaan di pesantren Bina Insani dilakukan melalui jalur ekstrakurikuler dan program 
unggulan. Jalur kewirausahaan melalui ekstrakurikuler diperuntukkan bagi para siswa yang pemula di tingkat sekolan lanjutan pertama; sedangkan jalur unggulan diperuntukkan bagi santri yang ingin mendalami benar kegiatan kewirausahaan dan diperuntukkan bagi santri tingkat atas.

Untuk mengoptimalkan pendidikan kewirausahaan di pesantren Bina Insani, para santri didampingi oleh pelatih dari luar pesantren. Dalam hal ini, pesantren Bina Insani lebih mengedepankan profesionalitas dalam pendidikan kewirausahaan. Selain pelatih dari luar, mereka juga didampingi para guru di sekolah sebagai pendamping teknis dalam pelakanaan program pendidikan kewirausahaan. Cara demikian, ternyata cukup efektif bagi kelancaran program kewirausahaan di pesantren Bina Insani. Disamping pendampingan teknis bagi para santri, pesantren Bina Insani juga mendapat pendampingan manajemen pendidikan kewirausahaan dari Kemendikbud, Kemenag dan UIN Jakarta.

Dari sisi pembiayaan, kegiatan kewirausahaan di pesantren Bina Insani didukung dari berbagai sumber, yaitu iuran santri, laba perputaran modal boga, sponsor dari Kemendikbud dan Kemenag. Banyaknya sumber dana di pesantren Bina Insani ini sangat menopang pelaksanaan kegiatan kewirausahaan.

Sementara itu, di pesantren al Ittihad Poncol Kabupaten Semarang agak berbeda pelaksanaan pendidikan kewirausahaan bagi para santri. Pendidikan kewirausahaan dilakukan terintegrasi dalam kegiatan santri, baik dalam kegiatan intrakurikuler maupun kegiatan non-kurikuler. Dalam praktiknya kegiatan intrakukuler berupa yasinan, khitobah, qira'ah, pengajian; sedangkan kegiatan non-kurikuler dalam praktiknya berupa kegiatan karnaval, pengajian, ta'ziran, dan khidmat kepada Kyai (ngabdi ndalem).

Model pendidikan kewirausahaan yang terintegrasi dalam proses pembelajarannya dilakukan dengan menginternalisasikan nilai-nilai kewirausahaan ke dalam semua pembelajaran. Hasil yang diperoleh berupa kesadaran akan pentingnya nilai-nilai, terbentuknya karakter wirausaha dan pembiasaan nilai-nilai kewirausahaan ke dalam tingkah laku peserta didik sehari-hari melalui proses pembelajaran baik yang berlangsung di dalam maupun di luar kelas (Anita (2012:7). 
Kegiatan pembelajaran, selain untuk menjadikan peserta didik menguasai kompetensi (materi) yang ditargetkan, dapat juga dirancang dan dilakukan untuk menjadikan peserta didik mengenal, menyadari/peduli, dan menginternalisasi nilai-nilai kewirausahaan dalam perilaku keseharian. Namun, di pesantren Poncol pengintegrasian pendidikan kewirausahaan dalam kegiatan kurikuler ini dirancang secara sederhana tidak seperti dalam sistem klasikal formal persekolahan, karena sistem pendidikan di pesantren lebih dekat pada sistem informal dan fleksibel.

Tabel 2. Integrasi kegiatan di pesantren AlIttihad

\begin{tabular}{|c|c|c|c|}
\hline No & Nama Kegiatan & Kompetensi langsung & Nilai kewirausahaan \\
\hline 1 & Khitobah & Kemampuan dakwah & Rasa percaya diri \\
\hline 2 & Silat & Penguasaan jurus bela diri & $\begin{array}{l}\text { Berani menghadapi } \\
\text { tantangan }\end{array}$ \\
\hline 3 & Qiraah & $\begin{array}{l}\text { Kemampuan seni baca al } \\
\text { Qur'an }\end{array}$ & Rasa percaya diri \\
\hline 4 & Khidmat Kyai & $\begin{array}{l}\text { Memantu menyelesaikan } \\
\text { pekerjaan di rumah Kyai }\end{array}$ & $\begin{array}{l}\text { Kerja keras, tekun, } \\
\text { tabah, kreatif, inovatif }\end{array}$ \\
\hline 5 & $\begin{array}{l}\text { Organisasi } \\
\text { Komplek }\end{array}$ & $\begin{array}{l}\text { Memenuhi kebutuhan } \\
\text { anggota }\end{array}$ & Kepemimpinan \\
\hline 6 & Ta'ziran & $\begin{array}{l}\text { Memberi hukuman yang } \\
\text { membuat pelanggar jera }\end{array}$ & Jujur, tekun \\
\hline 7 & Karnaval & $\begin{array}{l}\text { Mempromosikan produk, } \\
\text { lembaga }\end{array}$ & Kreativitas, inovatif \\
\hline 8 & Yasinan & $\begin{array}{l}\text { Mendekatkan diri kepada } \\
\text { Allah }\end{array}$ & Kebersamaan \\
\hline
\end{tabular}

Dari sekian banyak kegiatan di pesantren Al Ittihad, baik kegiatan kurikuler maupun non-kurikuler, kegiatan Khidmat Kyai dianggap kegiatan yang penting dan banyak menanamkan nilai-nilai kewirausahaan bagi para santri. Kegiatan khidmat kyai atau disebut juga ngabdi ndalem mengandung nilai pengabdian dan sekaligus latihan kerja bagi para santri. Dalam mengabdi kyai, santri memiliki tugas menyelesaikan pekerjaan di rumah kyai seperti mencari kayu bakar, mengurusi peternakan lele, mengurusi sawah, mengurusi 
peternakan bebek, mencukupi kebutuhan air, memasak dan membersihkan rumah kyai. Mengabdi kepada kyai juga dipahami sebagai sarana untuk 'ngalap berkah' kepada kyai atas ilmu yang diajarkan kepadanya.

Dalam kegiatan ngabdi ndalem, ketiga model pola relasi santri dan kyai terpenuhi, yaitu : a) hubungan guru dan murid; b) hubungan orang tua anak; dan c) hubungan patron client. Dalam hubungan guru dan murid, menurut Nurcholis Madjid (1997:23) santri akan selalu memandang kyainya atau gurunya sebagai orang yang mutlak harus dihormati, bahkan dianggap mempunyai kekuatan ghaib yang membawa keberuntungan (berkah) atau celaka (mudarat). Hal yang paling ditakuti santri adalah kalau sampai ia disumpahi kyainya sehingga ilmunya tidak bermanfaat. Oleh karena itu santri selalu berusaha untuk taat kepada kyai agar ilmunya bermanfaat dan menghindarkan diri dari sikap yang mengundang kutukan dari kyai.

Peranan kyai sebagai juga orangtua, kyai merupakan tempat dimana santri mengadu, terutama jika santri mempunyai masalah yang tidak dapat dipecahkan sendiri (Galba, 2004:64). Hubungan patron-client berupa hubungan kyai dan santri yang diwarnai kepercayaan, wibawa, dan karisma, dimana hal tersebut merupakan nilai-nilai tradisi yang terdapat di pesantren. Nilai-nilai yang terdapat di pesantren menurut Sukamto (1999:79) mengandung tiga unsur yang mengarah kepada terbentuknya hubungan patron-client, yaitu: a) hubungan patron-client didasarkan pada pertukaran yang tidak seimbang, yang mencerminkan perbedaan status; b) hubungan patron-client bersifat personal, bahkan penghormatan santri ke kyai yang cenderung bersifat kultus individu; c) hubungan patron tersebar menyeluruh, fleksibel dan tanpa batas kurun waktunya.

Terhadap santri yang berkhidmat kyai, kyai tidak memberi upah bulanan kepadanya. Para santri yang ngabdi ndalem mendapat fasilitas makan di ndalem. Selain itu, mereka juga mendapat potongan pembayaran pondok sebesar 50\%. Dari total santri yang mondok di pesantren Al Ittihad Poncol, ada sekitar 60 an yang ngabdi ndalem. Kegiatan ngabdi ndalem dilakukan antara pukul $10.30-12.00$ siang. 


\section{Dampak pendidikan entrepreneurship}

Kegiatan pendidikan kewirausahaan di pesantren Bina Insani memberikan multidampak bagi pesantren dan para santri. Dampak tersebut berupa dampak ekonomi dan dampak terhadap penguatan soft skill para santri.

Dampak ekonomi terhadap terhadap pesantren berupa laba usaha yang dapat dimanfaatkan untuk perluasan lokasi pesantren dan lokasi unit usaha seharga Rp.700.000.000,-- Dana tersebut terkumpul dari laba usaha bidang boga, yaitu olahan makanan kecil berbahan baku singkong dan kerupuk lele. Cara demikian sangat positif untuk menopang eksistensi lembaga.

Dampak kewirausahaan di pesantren Bina Insani terhadap peningkatan soft skill santri berupa keterampilan berbisnis dan internalisasi nilai-nilai kewirausahaan santri seperti rajin, disiplin, menatap masa depan, ambil resiko. Dampak terhadap peningkatan keterampilan berbisnis santri dicapai melalui latihan kewirausahaan yang dilakukan sejak perancangan, produksi, pemasaran hingga analisis untung rugi. Dampak ini dirasakan oleh santri yang mengikuti program unggulan bidang kewirausahaan. Dampak terhadap peningkatan soft skill santri dalam internalisasi nilainilai kewirausahaan dirasakan santri yang mengikuti program kewirausahan melalui ekstrakurikuler maupun program unggulan. Nilai-nilai kewirausahaan yang dirasakan santri setelah mengikuti program kewirausaah di pesantren Bina Insani antara lain rajin, disiplin, menatap masa depan, ambil resiko. Nilai-nilai tersebut telah mewujudkan dalam sikap pribadi para santri yang mengikuti program kewirausahaan.

Sementara itu, bagi santri di pesantren Al Ittihad Poncol, dampak partisipasi santri dalam berbagai kegiatan kurikuler maupun non-kurikuler di pesantren adalah adanya internalisasi nilai-nilai kewirausahaan pada diri santri seperti rasa percaya diri, kerja keras, tekun, jujur, tabah, suka tantangan, kepemimpinan, kreatif, dan inovatif.

Nilai-nilai kewirausahaan tersebut mewujud dalam perilaku keseharian santri. Apalagi para santri lebih beroientasi kerja dalam sektor swasta ke depannya, nilai-nilai tersebut sangat mendukung 
bagi santri dalam berwirausaha kelak. Menurut Gagne (dalam Dimyati,2006:206), hasil belajar dapat berbentuk keterampilan intelektual, kemampuan kognitif, informasi verbal, keterampilan motorik, dan internalisasi nilai dalam sikap.

\section{Kendala dan solusi}

Masalah yang muncul dalam pelaksanaan pendidikan kewirausahaan di pesantren Bina Insani adalah pemasaran, SDM, sustainability product, dan teknologi.

Masalah bidang pemasaran dirasakan bagi produk unit usaha di pesantren Bina Insani, seperti snak olahan dari singkong, kerupuk lele, dan pupuk cair. Pemasan produk tersebut selama ini baru terbatas di lingkungan pesantren dan belum mampu menjangka pasar luas. Akibatnya perputaran modal dan laba produksi makanan olahan sangat lambat. Di sisi lain, ada konsumen yang menginginkan setoran produk olahan makan rutin setiap hari, namun unit usaha di pesantren Bina Insani belum mampu memenuhinya karena terbatasnya bahan baku dan kemampuan produksi.

Masalah bidang sumber daya manusia yang dirasakan dalam kegiatan kewirausahaan di pesantren Bina Insani adalah keberlangsungan tenaga produksi dan keaktivan pelatih. Keberlangsungan tenaga produksi menjadi persoalan karena tenaga produksi di beberapa unit usaha harus selalu berganti seiring dengan habis masa studinya para santri. Para tenaga pengganti produksi pada unit usaha di pesantren Bina Insani terkadang kurang memiliki kompetensi yang setara dengan tenaga sebelumnya. Akibatnya, hasil produksi kurang bisa memenuhi standar produk dan waktu yang ditentukan. Apalagi sebagian diantara tenaga produksi adalah tenaga sambilan, sehingga tidak maksimal.

Masalah lain yang muncul adalah masalah teknologi, yaitu alat pengecek amuba air. Para santri merasa kesulitan menggunakan alat tersebut untuk mengecek kadar amuba di air, karena kalau hasilnya tidak akurat maka berakibat matinya ternak lele. Mereka selalu merasa was-was dengan hasil tes amuba yang dilakukan, karena dampaknya fatal. 
Upaya yang dilakukan untuk mengatasi masalah tersebut adalah dengan bantuan para guru untuk penyiapan bahan baku dan mengisi jam pelatih yang kosong. Dalam hal pemenuhan permintaan produksi, pesantren berencana mencari pekerja untuk mengolah bahan baku menjadi produk makanan olahan. Demikian juga dalam hal penataan, pesantren Bina Insani berencana mengelola kegiatan kewirausahaan lebih serius dengan manajemen yang tertata.

Di pesantren Poncol Kabupaten Semarang, permasalahan yang muncul adalah berasal dari sumber daya manusia, yaitu ada sebagian santri yang menyalahgunakan kewenangannya dalam kegiatan ngabdi ndalem. Ada santri yang tidak masuk sekolah dengan alasan mendapat tugas kerja dari kyai, padahal tidak; dalam kegiatan khitobah sebagian santri terlihat kurang semangat mengikuti kegiatan dan izin pulang ketika mendapat jatah petugas; dalam kegiatan qira'ah bagi santri yang suaranya kurang bagus enggan mengikuti kegiatan latihan seni baca al Qur'an.

Dalam mengatasi masalah tersebut, pengurus melakukan klarifikasi kepada kyai tentang kegiatan para santri yang mengikuti ngabdi ndalem. Selan itu, pengurus pesantren juga mengajak para santri melakukan mujahadah agar hatinya dibukakan oleh Allah sehingga memiliki kesadaran dalam mengikuti kegiatan di pesantren. Bagi para santri yang sering menghindar ketika mendapat jatah petugas khitobah, maka pengurus menjadwal ulang pada kegiatan yang akan datang.

Menurut Karl Vesper (Wianardi.2004:37), problem yang muncul dalam kegiatan wirausaha berkisar pada tiadanya konsep bertahan, kurang dikenalnya pasar, kurangnya keterampilan teknikal, kurang modal awal, kurangnya pengetahuan tentang bisnis, puas dengan diri sendiri, motivasi lemah, stigma sosial, keterikatan pada pekerjaan, distransaksi karena tekanan waktu, kendala-kendala yuridis, pengaturan birokrasi yang kaku, proteksionisme, monopoli, kendalakendala karena paten-paten. Kalau dikaitkan dengan pendapat Karl Vesper tersebut, maka persoalan yang muncul di pesantren adalah kurangnya konsep wirausahaan, kurang dikenalnya pasar, motivasi lemah, tekanan waktu (terbatasnya waktu), keterikatan pada pekerjaan, dan kurangnya keterampilan teknikal. 


\section{Simpulan}

Pendidikan kewirausahaan diarahkan untuk mempersiapkan santri dalam menghadapi kehidupan kelak setelah lulus. Dalam hal pekerjaan sebenarnya sudah diatur oleh Allah, namun manusia harus berusaha untuk mempersiapkan diri dengan keterampilan secukupnya.

Kegiatan kewirausahaan di pesantren dilaksanakan melalui beberapa jalur, yaitu a) jalur program khusus unggulan; b) jalur kurikuler; c) jalur ekstrakurikuler; dan d) jalur non-kurikuler. Pesantren modern lebih memilih jenis kegiatan keterampilan praktis inovatif dengan mengakomodasi potensi daerah / lokal; sementara pesantren salaf memilih membekali santri dengan ijazah formal dan jenis keterampilan agraris pedesaan sebagai latihan kerja para santri.

Kegiatan kewirausahaan di pesantren mampu memberi dampak ekonomi dan life skill kepada para santri. Dampak ekonomi mampu memberi kontribusi kepada pesantren dalam pengembangan lahan dan subsidi kebutuhan pribadi santri; sedangkan dampak life skill berupa tertanamnya nilai-nilai kewirausahaan dalam diri santri. Nilai-nilai tersebut meliputi rasa percaya diri, kerja keras, tekun, jujur, tabah, suka tantangan, rajin, disiplin, menatap masa depan, ambil resiko, kepemimpinan, kreatif, dan inovatif.

Masalah yang muncul dalam kegiatan kewirausahaan di pesantren adalah masalah berasal dari : a) buman resources; b) masalah teknologik; c) masalah manajemen. Untuk mengatasi masalah tersebut, pihak pesantren selalu melakukan kordinasi dengan pihak terkait dan berusaha memperbaiki manajemen kewirausahaannya. 


\section{Daftar Pustaka}

Dimyati dan Mujiono. 2006. Belajar dan Pembelajaran. Jakarta:Rineka Cipta

Eka Febri Anita. 2012. Aplikasi Pendidikan Kewirausahaan Dalam Dunia Pendidikan, diakses dari http://assetanita.blogspot.com/ pada tanggal 29 November 2017 pukul 21.15 WIB

Fadhil Rahman. 2013. Profil PPM Bina Insani, diakses dari http://fadhilelfast-stylized.blogspot.co.id/2012/03/profil-ppm-bina-insanisusukan.html pada tanggal 1 Desember 2017 pukul 09.20 WIB

Fasli Jalal \& Dedi Supriyadi (Ed). (2001). Reformasi Pendidikan Dalam Konteks Otonomi Daerah. Adicita:Yogyakarta

Ferawati. 2016. Entrepreneurship santri di Pondok Pesantren entrepreneur al-Mawaddah Honggosoco Jekulo Kudus (Studi living Qur'an), diakses dari http://eprints.stainkudus. ac.id/468/ pada tanggal 1 Desember 2017 pukul 23.15 WIB

Galba, Sindu. 2004. Pesantren Sebagai Wadah Komunikasi. Jakarta: PT. Rineka Cipta.

Hasbullah. 1999. Sejarah Pendidikan Islam di Indonesia:Lintasan Sejarah Pertumbuhan dan Perkembangan. Jakarta : PT Raja Grafindo Persada.

Handayani, Ririn. 2013. Kewirausahaan berbasis pesantren, diakses dari http://www.ririnhandayani.com/2013/01/menggagaspesantren-sebagai. html), pada tanggal 12 April 2017 pukul 19.14

Inayatul Khusnah. 2011. Pesantren dan entrepreneurship : Upaya Pesantren Riyadhul Jannah Pacet Mojokerto dalam pembentukan jiwa entrepreneurship santrinya, diakses dari http://digilib.uinsby.ac.id/9044/, pada tanggal 1 Desember 2017 pukul 19.30 WIB

Ki Bagus Kusuma. 2015. Mengenal Profil seputar Pondok Pesantren Bina Insani Salatiga, dikutip dari http://artofmanlines. blogspot.co.id /2015/11 / mengenal- profil-seputar-pondok. html pada tanggal 1 Desember 2017 pukul 11.00 WIB 
Madjid, Nurcholis. 1997. Bilik-Bilik Pesantren Sebuah Potret Perjalanan. Jakarta: Paramadina.

Malik M.,dkk. 2007. Modernisasi pesantren. Jakarta:Balai penelitian dan pengembangan agama

Manfred Ziemek. 1989. Pesantren dalam perubahan sosial. Jakarta:P3M

Merriam, Sharan B. \&Tisdell, Elisabeth J. 2016. Qualitative research: A guide to design and implementation. San Francisco: Jossey-Bass.

Miles, Matthew B. \& Huberman, A. Michael. 1994 . Qualitative data analysis. London: Sage Publications.

Moleong, Lexy J. 2002. Metodologi penelitian kualitatif. Bandung: PT. RemajaRosdakarya.

Mochtar Buchori. 2001. Pendidikan Antisipatoris. Yogyakarta:Kanisius

Munif Chatib. 2009. Sekolahnya Manusia. Bandung:Kaifa

Nata, Abuddin. 2001. Perspektif Islam tentang Hubungan Guru Murid. Jakarta: PT. Raja Grafindo Persada.

Novan Ardy Wiyani. 2012. Teacherpreneurship. Yogyakarta: Ar Ruzz Media

Ponpes Poncol. 2015. Sejarah Pondok Pesantren Al Ittihad Poncol, diakses dari http://pondokponcol.blogspot.co.id/2015/02/sejarahpondok pesantren 22. html pada tanggal 1 Desember 2017 pukul 08.30 WIB

Rusli, M. 2010. Sejarah, metodologi, sistem, tujuan pesantren, diakses dari http:// ruslyboyan.blogspot.co.id/2010/08/sejarahmetodologi-sistem-tujuan.html pada tanggal 1 Desember 2017 pukul 11.15 WIB

Sigit Wahyono. 2010. Inovasi Hidden Curriculum Pada Pesantren Berbasis Entrepreneurship (Studi Kasus di Pondok Pesantren Al-Isti'anah Plangitan Pati), diakses dari http://eprints. walisongo.ac.id/3263/1/ 3105129_Coverdll.pdf pada tanggal 2 Desember 2017 pukul 23.22 WIB

Syaiful Bahri Djamarah. 1994. Hasil Belajar Mengajar. Jakarta:Rineka Cipta 
Thomas W.Zimmerer \& Norman M.Scorborough, 2009, Essential of Entrepreneurship and Small Bussines Management (terj.Deny Arnos Kwary). Jakarta: Salemba Empat

Tilaar, HAR. (2004). Paradigma baru pendidikan nasional. Jakarta: Rineka Cipta

Wianardi.2004. Entrepreneur dan entrepreneurship. Jakarta:Pranata Media

Yin, Robert K. 2010. Qualitative research: From start to finish. New York: The Guilford Press.

Yin, Robert K. 2008. Case study research: Design and methods. London: Sage Publications.

Zamakhsyari Dhofier.1983. Tradisi Pesantren Studi tentang Pandangan Hidup Kyai. Jakarta:LP3S 